УДК 528.87

(C) М.А.Федонюк, к.г.н., В.В.Федонюк, к.г.н.

Луцький національний технічний університет

\title{
ВИКОРИСТАННЯ IHСТРУМЕНTIB EOS DATA ANALYTICS ДЛЯ МОНІТОРИНГУ СІЛЬСЬКОГОСПОДАРСЬКИХ ЗЕМЕЛЬ
}

Розглянуто можливості використання кількох онлайнсервісів аналізу супутникових знімків для моніторингу трунтів та посівів. Описано особливості роботи з продуктами EOS LandViewer ma EOS Crop Monitoring. Окреслено основні можливості та наведено приклади використання цих інструментів у сільському господарстві.

EOS LANDVIEWER, NDVI, EOS CROP MONITORING, ДИСТАНЦІЙНІ МЕТОДИ, МОНІТОРИНГ ПОСІВІВ

Постановка проблеми. Успішний розвиток сільського господарства сьогодні значною мірою прив'язаний до розвитку та застосування сучасних інформаційних технологій. Дистанційне зондування землі та обробка отриманих даних за допомогою ГІС (геоінформаційних систем) дозволяє, зокрема, оперативно виявляти зміни стану посівів та приймати відповідні агротехнічні рішення.

I якщо раніше проведення супутникового чи аерофотознімання полів було прерогативою лише крупних компаній, то зараз з'являється чимало технологій та інструментів 
дистанційного моніторингу, доступних практично кожному. Одним iз розробників таких інструментів є компанія EOS Data Analytics, яка надає ряд сервісів 3 постачання, обробки та аналізу мультиспектральних космічних знімків, чимало 3 яких можна ефективно використовувати в аграрній сфері.

Аналіз попередніх досліджень і публікацій. Застосування дистанційних даних для моніторингу сільськогосподарських земель почалось ще у 1980-х роках, але довгий час було обмежене малою доступністю космічних знімків та їх відносно низькою якістю. Інтенсивний розвиток наукових досліджень у цьому напрямку почався 3 кінця 1990-поч.2000 років. В Україні питанням агромоніторингу за матеріалами дистанційного зондування були присвячені праці Т.М.Шадчиної, С.Кохан, А.А. Москаленко, С.Станкевич, В.О.Ушкаренка, В.В.Морозова [2, 4, 6] та ін.. 3'явились також комплексні праці по застосуванню ГІС та ДЗЗ в агросфері $[1,3,5]$.

В останні кілька років ця тематика стала присутня у десятках щорічних публікацій науковців НАН України, університетів Києва, Харкова, Львова, Херсона, Рівного та ін., з'явились також науково-популярні статті про дистанційний моніторинг грунтів (наприклад, на 50northspatial.org/ua/category/soil-science).

Разом 3 тим, конкретних досліджень щодо застосування інструментів EOS Data Analytics для цих цілей майже немає, вони лише побіжно згадуються в ряді статтей як джерело отримання чи обробки даних. Тому ми вирішили присвятити окрему публікацію саме особливостям застосування цих продуктів в аграрній сфері.

Мета дослідження - окреслити та показати на прикладах основні можливості та інструменти сервісів EOS Data Analytics для моніторингу в сільському господарстві.

Результати дослідження. Компанія EOS (Earth Observing System) Data Analytics зареєстрована та працює в США, але офіси розробників знаходяться в багатьох країнах, в т.ч. 43 них - в Україні. Через велику частку українців та їхній внесок у створення і розвиток компанії, часто іiі називають «американською 3 українським корінням». Перший публічний продукт - LandViewer, що надає великі масиви доступних космознімків із додатковими функціями геоінформаційної обробки.

Крім LandViewer, на сьогодні представлені нові сервіси, більшість з яких об'єднані в хмару EOS Platform: EOS Engine, EOS Storage, EOS Processing, EOS Vision, EOS Lidar, EOS Crop Monitoring. Частина 3 них мають вузьку комерційну спрямованість, 
але більшість є загальнодоступною. EOS Storage надає хмарне сховище (безкоштовно - 256ГБ) для зберігання, перетворення та спільної роботи над космічними знімками, EOS Processing надає інструменти аналізу та класифікації космознімків (в т.ч. калібрування та атмосферна корекція, ідентифікація доріг, населених пунктів, лісів, визначення контурів полів і т.п.), EOS Vision дає можливість формування SQL-запитів, числової та графічної обробки геопросторової інформації.

Наш досвід роботи та апробації цих сервісів на кафедрі екології та агрономії Луцького НТУ дозволяє виокремити 2 з них, що $\epsilon$ доступними, простими у користуванні та найбільше відповідають цілям агромоніторингу. Це EOS LandViewer та EOS Crop Monitoring, можливості яких розглянемо далі детальніше.

EOS Crop Monitoring (eos.com/crop-monitoring) $є$ новим спеціалізованим сервісом, призначеним виключно для моніторингу стану посівів. Він базується на автоматичній класифікації величезних масивів космічних знімків за фільтрами, призначеними для ідентифікації стану рослинних угруповань. Більшість територій сільськогосподарських районів уже покриті такою класифікацією, за якою визначено контури полів та навіть види вирощуваних культур по сезонах 2016, 2017, 2018 років (рис.1).

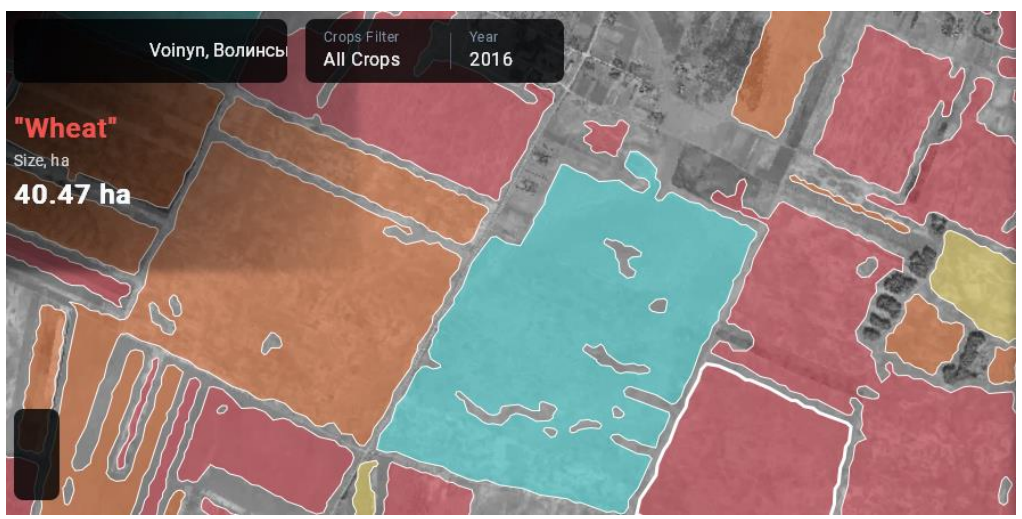

Рис.1 - Приклад автоматично класифікованих полів у EOS Crop Monitoring (частина Локачинського району Волинської області)

Втім, як бачимо, автоматична класифікація має свої недоліки, оскільки контури багатьох полів $є$ неточними, iз розривами та виступами. Також на невеликих площах трапляються випадки неправильної ідентифікації вирощуваних с/г культур. 
Для детального коректного моніторингу пропонується додати свої поля (add field) - намалювавши їх полігонами на карті, або вибрати вже класифіковані, або ж завантажити їх геопросторовим файлом. У кожному разі потім $\epsilon$ можливість вручну відредагувати інформацію (edit field) як по контурах поля, так і по культурах, які вирощувалися за останні роки.

Після додавання власних полів у систему для них починає відображатись поточна та архівна інформація як щодо основних погодних умов, так і щодо стану рослинності, оціненого на основі космічних знімків (рис.2).

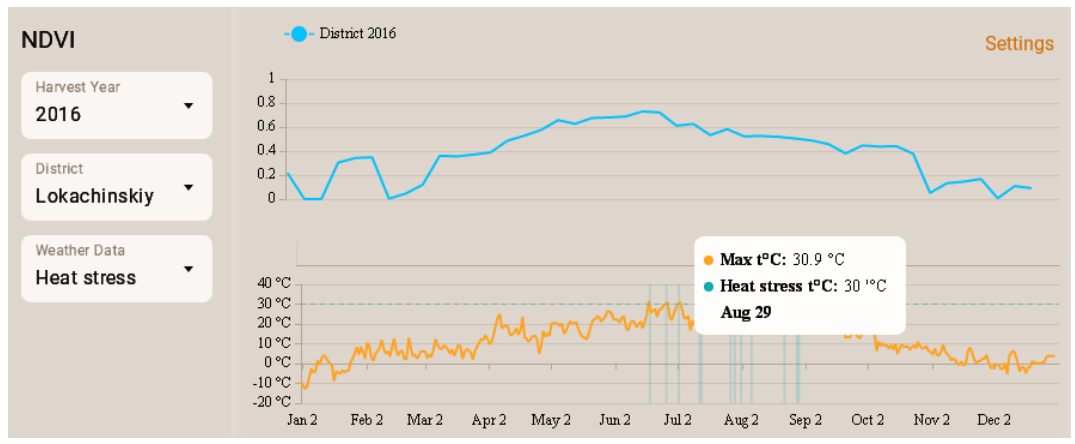

Рис. 2 - Приклад відображуваної інформації щодо стану посівів та погодних умов у EOS Crop Monitoring

За замовчуванням відображається інформація про стан рослинності за індексом NDVI та температурні умови за попередній рік. За інші періоди для території Волинської області значення NDVI $є$ з 2016, а кліматична інформація - 32015 року. Серед погодного архіву, окрім температури, можна вибрати також значення кількості опадів, періодів температурних стресів та зимової загибелі рослин. Побудовані графіки $є$ інтерактивними, при наведенні на конкретну дату відображається відповідна інформація саме на цю добу. Крім цього, на бічній панелі відображається просторова інформація (площа поля, координати), сівозміни останніх років (можна вручну додати дати посіву) та поточна погода (температура, вологість, хмарність, опади, швидкість вітру, атмосферний тиск).

Зауважимо, що до погодних даних у сервісі варто ставитись 3 обережністю, адже вони постачаються не з реальних метеостанцій у місцевості розташування поля, а як точкова вибірка із цифрових 
регіональних моделей, відповідно в окремих випадках можлива суттєва похибка. Наприклад, у Луцькому районі за період березняквітня 2019p. кількість опадів, показана у додатку, була майже на $25 \%$ більшою, аніж зафіксована нашими реальними інструментальними метеорологічними спостереженнями. Але в більшості погодні дані все ж є репрезентативними і дозволяють відстежувати загальні тенденції змін агрокліматичних умов.

Отримана у сервісі інформація дозволяє обгрунтовано підійти до планування агротехнічних рішень у конкретних умовах. Для цього також передбачений планувальник завдань, які можна просторово прив'язувати до вибраних точок поля. Ще більше функцій у зручному форматі передбачено у новому додатку Crop Monitoring для Android, який поки що доступний у PlayMarket y beta-версії для тестування.

Загалом, EOS Crop Monitoring $\epsilon$ досить зручним багатофункціональним інструментом для агрокомпаній. Але недоліком, на нашу думку, $\epsilon$ використання автоматичної класифікації рослинності за середніми значеннями лише одного показника, що не завжди дає змогу ефективно візуалізувати просторово-часові відмінності стану посівів. Для значно детальнішого моніторингу можна використати можливості сервісу LandViewer.

LandViewer $€$ хмарним кросбраузерним сервісом, доступним з будь-якого пристрою, підключеного до Інтернету. На сьогодні це найкращий продукт компанії EOS із багатим функціоналом та хорошою доступністю. Зазначимо, що технічні вимоги до роботи із сервісом мінімальні, він цілком працездатний навіть на старих ПК із ОC Windows XР та 1 ГБ ОЗП (на відміну від інших продуктів EOS Platform, які потребують набагато більше ресурсів).

Базовий перегляд LandViewer відкритий для кожного, але для повноцінної роботи 3 сервісом потрібна реєстрація. Для безкоштовних облікових записів наявне обмеження перегляду 10 знімків на добу, але для більшості завдань такої кількості цілком достатньо.

Сервіс надає доступ до знімків із більше десятка різних супутників. Для нашої території найкориснішими з цього переліку $є$ мультиспектральні знімки Landsat-8 та Sentinel-2, що мають відповідно по 11 та 12 каналів зйомки із різними хвильовими діапазонами, що дозволяє отримувати значні масиви інформації про стан ландшафтів, лісів, с/г рослинності тощо. Зйомка 3 цих апаратів ведеться переважно в оптичному та ближньому інфрачервоному 
діапазонах (від 0,443 до 1,4-2,19мкм), а у Landsat-8 також у дальньому (тепловому) інфрачервоному діапазонах (10,3-12,5мкм). Розрізнення знімків складає від 10 до 60м у Sentinel-2 та від 15 до $100 \mathrm{M}$ y Landsat-8 $[7,8]$.

Безпосереднім постачальником знімків Sentinel-2 $\epsilon$ Європейська космічна агенція (ESA), a Landsat-8 - Американська геологічна служба (USGS). Але робота 3 цими знімками у LandViewer дає багато додаткових функцій та можливостей: фільтрування, каліб-рування, корекцію, створення власної області інтересів, вимірювання відстаней та площ довільних конфігурацій, інструменти порівняння різночасових знімків, розрахунок вегетаційних індексів і т.п.

Зручним є інструмент пошуку знімків за фільтрами дати, хмарності, висоти Сонця, типу супутника.

Однією 3 найважливіших функцій для сільського господарства $\epsilon$ автоматичний обрахунок різноманітних похідних індексів, утворених різними комбінаціями каналів зйомки. Найвідоміший 3 них - NDVI (нормалізований диференційний вегетаційний індекс), що розраховується як відношення різниці інтенсивності відбитого випромінювання у ближньому інфрачервоному (NIR) та червоному каналі до їхньої суми (в червоній зоні високим $є$ поглинання хлорофілу, а у NIR-зоні - його відбивна здатність). Показник змінюється від -1 до 1 , максимальні значення свідчать про інтенсивний розвиток рослинності. Зміни NDVI протягом вегетаційного сезону сигналізують про різні фази розвитку с/г культур.

Як ми вже зазначали, саме автоматичний аналіз індексу NDVI покладено в основу EOS Crop Monitoring. Натомість у LandViewer є, окрім NDVI, візуалізація більше 10 інших індексів та показників: SAVI (soil adjusted vegetation index), ARVI (atmospherically resistant vegetation index), EVI, GCI, SIPI, NBR, «Agriculture» «Healthy vegetation» та ін. Більшість із них також оцінюють стан рослинності, але за допомогою кожного разу дещо інших ознак, пов'язаних із корекцією на відбиття грунту, атмосфери, хмар, із поглинанням хлорофілу чи каротиноїдів, фокусуванням на вогнищах ураження рослин тощо. На рис.3. показано приклад відображення с/г земель у 4 з таких індексів.

При детальнішому аналізі помічаємо, що при схожості загальної картини, на багатьох ділянках можна простежити певні просторові відмінності, які непомітні на інших каналах. Тому деталізований моніторинг стану посівів потребує паралельного аналізу принаймні кількох різних вегетаційних індексів. 
Крім власне «рослинних» індексів, важливо відстежувати також зміни показника NDWI (нормалізований індекс води), який частково відображує рівень вологості грунту.
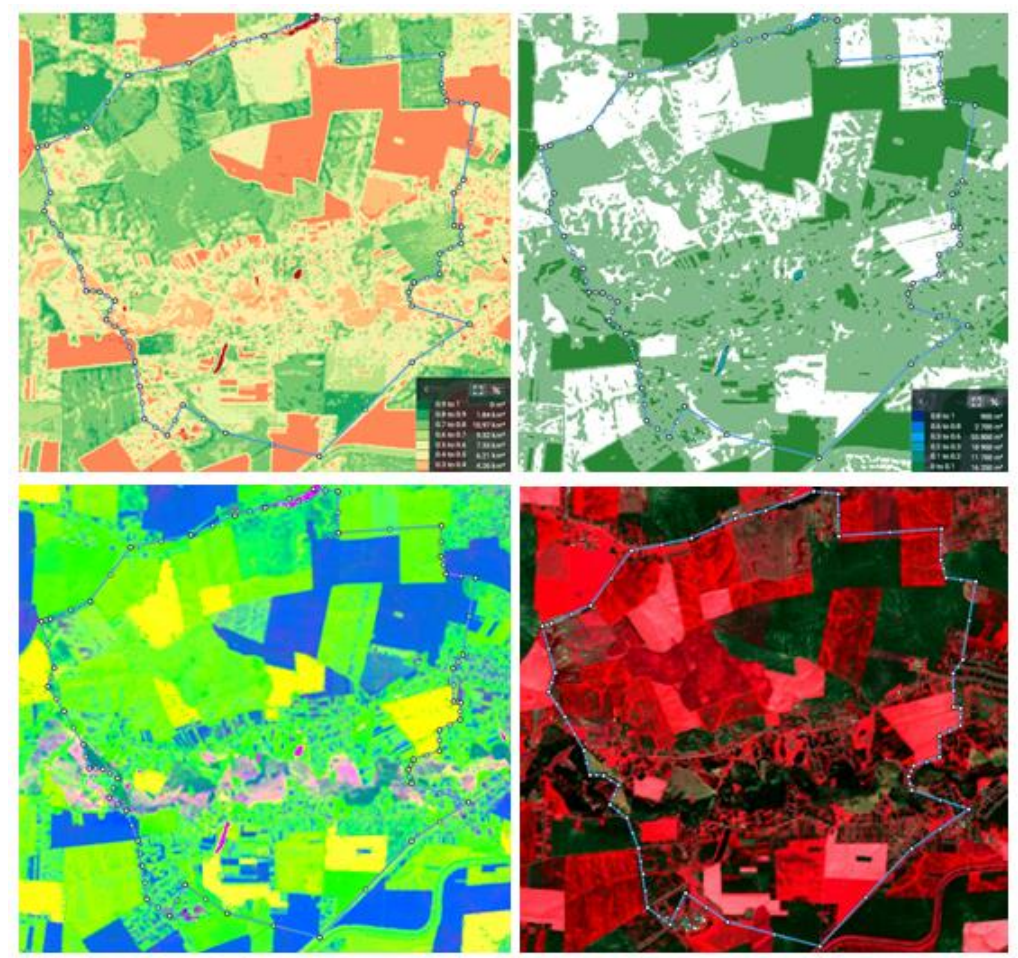

Рис.3 - Відображення однієї ділянки у різних комбінаціях каналів NDVI, NDWI, «Atmospheric penetration», «Color Infrared» (знімок Landsat-8 7.05.2019, Луцький район)

Окрім власне візуального аналізу, який може бути суб'єктивним, Landviwer пропонує також кількісні показники по трьох індексах - NDVI, NDWI, NDSI. Для отримання такої інформації потрібно намалювати/завантажити область інтересу та відкрити вкладку «Аналіз часових рядів», у ній вибрати індекс, джерело даних та період аналізу (від 1 місяця до 10 років). Програма автоматично будує часовий ряд із візуалізованими значеннями (рис.4). 


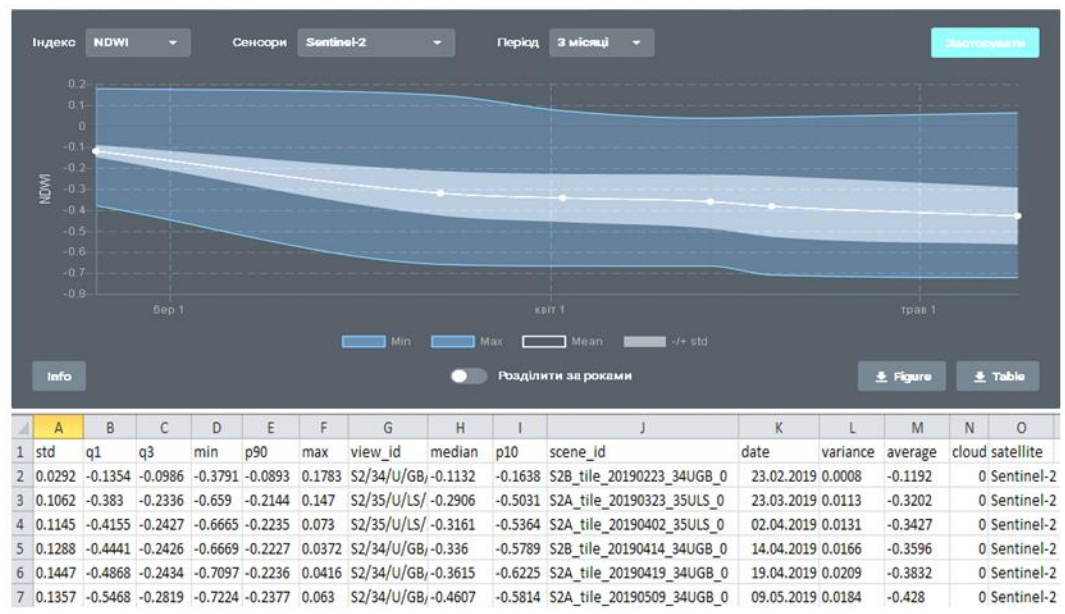

Рис.4 - Приклад отримання вихідних даних обчислення індексу NDWI та його унаочнення за вибраний період

Ці дані можна завантажити як у вигляді діаграми, так i табличного файлу. Кількість значень може суттєво варіювати залежно від метеоумов за досліджуваний період, оскільки такі розрахунки проводяться тільки для знімків 3 мінімальною хмарністю.

Доцільно за такою інформацією створювати свою базу даних для конкретних полів, та постійно оновлювати їі через функцію підписки на нові знімки своєї AOI (area of interest).

Висновки. Як бачимо, проаналізовані сервіси Crop Monitoring та LandViwer дають великі обсяги дистанційної інформації та інструментів іiі аналізу, корисних для ефективного ведення рослинництва. При цьому надаються як готові до використання автоматично класифіковані дані, так і можливості для власного пошуку та аналізу геопросторової інформації про стан сільськогосподарських земель. Подальше підвищення деталізації такого моніторингу можливе із паралельним застосуванням польових методів: кількаразові визначення характеристик посівів у визначений час у конкретних точках із наступним співставленням цих параметрів із показниками вегетаційних індексів на космознімках за цей період. 


\section{Література}

1. Зацерковний В. І. Дистанційне зондування Землі. Фізичні основи: навч. посіб. / В.І. Зацерковний. - Ніжин : НДУ ім. М. Гоголя, 2018. - 380 с.

2. Кохан, С.С. Дистанційний моніторинг земельних ресурсів / С.С.Кохан. - К.: НАУ (2004).

3. Морозов В.В. Геоінформаційні технології в агросфері / В.В. Морозов, К.С. Лисогоров, Н.М. Шпоринська. - Херсон : ХДУ, 2007. -223 c.

4. Станкевич С. Комплексна обробка багатоспектральних аерокосмічних зображень для виявлення сільськогосподарських угідь / С.Станкевич, А. Васько // Сучасні досягнення геодезичної науки та виробництва, випуск II (22), 2011 - С.171-175.

5. Трускавецький С.Р. Порівняльний аналіз різних підходів до картографування грунтів / С.Р. Трускавецький, Л.П. Коляда // Вісник ХНАУ № 2, 2013, Грунтознавство. - С.12-15.

6. Ушкаренко В.О. Системи управління базами даних ГІС для моніторингу грунтів / В.О. Ушкаренко, В.В. Морозов, О.В. Морозов та ін. - Херсон : ХДУ, 2007. -112 с.

7. Sentinel-2 MSI: Overview [Електронний ресурс] Режим доступу: https://sentinel.esa.int/web/sentinel/user-guides/sentinel-2msi/overview

8. Landsat Science [Електронний ресурс] Режим доступу: https://landsat.gsfc.nasa.gov/ 